\title{
ETHNOCULTURAL ASPECT OF THE STUDY OF THE SOCIAL SPHERE AS THE BASIS OF HUMAN LIFE
}

\author{
(C) Vadim N. Goncharov, Olga Y. Kolosova \\ North-Caucasus Federal University, Krasnodar University of Ministry of Internal Affairs \\ of Russian Federation, Stavropol, Russian Federation \\ science-almanac@mail.ru
}

The whole culture of the ethnos: material, directly related to life support, social and spiritual, is determined, organized, structured under the influence of the strategy of its life. The livelihood structure of an ethnos consists of a complex of necessary components. One of them is the culture of life support, which includes both rational and irrational elements, specific elements of ideology. A superficial attitude to the traditional way of running of the household leads not only to the degradation of the environment, but most of all to a change in certain, essential features of ethnic consciousness, which has been formed over the centuries. Ignoring the culture of livelihood in the most negative way affects the development of ethnic groups, undermines the foundations of their existence. Culture is a set of behavioral models that a person assimilates in the process of socialization and the adoption of his cultural role. Culture contains such behavioral patterns, following which makes it possible to most rationally use the available geographic and climatic conditions. These behavioral models are passed down from generation to generation in the process of socialization and are the main mechanism by which human groups adapt to the environment. A person lives not just in a social, but also in an ethnic environment. Ethnicity functions due to the fact that it develops a certain system of socialization of its members, in the framework of which the production and transmission of culture, the formation of the young generation in its image and likeness take place.

Key words: culture, ethnos, ethnic consciousness, cultural tradition, ethnocultural environment, socialization, social institutions.

\section{[В.Н. Гончаров, О.Ю. Колосова Этнокультурный аспект исследования социальной сферы как основы жизнедеятельности человека]}

Вся культура этноса, материальная, непосредственно связанная с жизнеобеспечением, социальная и духовная, детерминируется, организуется, структурируется под влиянием стратегии его жизнедеятельности. Структура жизнеобеспечения этноса состоит из комплекса необходимых компонентов. Один из них - культура жизнеобеспечения, включающая в себя как рациональные, так и иррациональные элементы, специфические элементы идеологии. Поверхностное отношение к традиционному способу ведения хозяйства ведет не только к деградации среды обитания, но и более всего к изменению определенных, существенных черт этнического сознания, которое формировалось веками. Игнорирование культуры жизнеобеспечения самым негативным образом сказывается на развитии этносов, подтачивает основы их существования. Культура - это совокупность моделей поведения, которые человек усваивает в процессе социализации и принятия им своей культурной роли. В культуре содержатся такие модели поведения, следование которым дает возможность наиболее рационально использовать имеющихся географические и климатические условия. Эти поведенческие модели передаются из поколения в поколение в процессе социализации и являются основным механизмом, посредством которого человеческие коллективы адаптируются к окружающей среде. Человек живет не просто в социальной, а в этнической среде. Этнос функционирует благодаря тому, что вырабатывает определенную систему социализации своих членов, в рамках которой происходит воспроизводство и передача культуры, фрормирование молодого поколения по своему образу и подобию.

Ключевые слова: культура, этнос, этническое сознание, культурная традиция, этнокультурная среда, социализация, социальные институты.

Vadim N. Goncharov - Ph.D. in Philosophy, Associate Professor, North-Caucasus Federal University, Stavropol, Russian Federation.

Olga Y. Kolosova - Ph.D. in Philosophy, Associate Professor, Krasnodar University of the Ministry of Internal Affairs of the Russian Federation, Stavropol branch, Stavropol, Russian Federation. 
Гончаров Вадим Николаевич - доктор философрских наук, доцент, Северо-Кавказский федеральный университет, г. Ставрополь, Российская Федерация.

Колосова Ольга Юрьевна - доктор философрских наук, доцент, Краснодарский университет Министерства внутренних дел Российской Федерации, Ставропольский филиал, г. Ставрополь, Российская Федерация.

Socialization is the development and self-realization of a person throughout his life in the process of assimilation and reproduction of the culture of society, the process and result of the inclusion of a growing person in society through the assimilation and more or less active reproduction by a person of social experience, historically accumulated culture. "Culture is understood as the inner essence of human ideas ..." [14, p. 3-9]. "Culture is an essential characteristic of the social sphere of society; it is inseparable from the social activity of man" [6, p. 74-78]. All symbolic activity is a social form of cooperation, preserves the social mode of functioning along the entire path of development to the highest points.

Ethnization is a type of socialization, the process of assimilation and acquisition by people of a certain range of values of a given ethnic group, most intensively flowing in the first years of life (mainly through family, traditions, way of life, customs). Ethnization includes the formation of a person's ethnic stereotypes, ethnic self-awareness, ideas about the lifestyle features of his community, his acquisition of the rules of conduct and etiquette common in her (this community). In the structure of an ethnic group, mechanisms of ethnic socialization are formed, providing stability, continuity, integration and differentiation, kinship and alienation in the history of ethnic groups.

Ethno-social structures are the main source of knowledge acquisition and construction of intellectual structures. Intentionality is one of the main elements of the socialization of the individual, one of the conditions for the transmission of new ethnic values to new generations. Socialization consists in the selective assimilation of various influences by a person, defines "... the quality of a person and the ability of social subjects to purposefully interact with the environment" [10, p. 282-284], "the complex interaction of various types of social communication" [2, p. 5-10]. As a personality, a person is formed in the social system through focused and thoughtful education. Ethnic-sociocultural differences are inseparable from specific styles of knowledge acquisition, selection and processing of information, largely determined by economic and ethnocultural factors, one way or another determine the socio-cultural development of society [7, p. 123-128].

The ethnocultural environment presupposes the development of commonality of psychological features and forms of livelihood, cognitive orientation, ethnic identity, stereotype and mentality among the representatives of this ethnic group, which are a function of a single ethnic picture of the world. These concepts are the most commonly used in studies and theories regarding problems of ethnic relations, prejudice, intergroup perceptions and conflicts.

The significance of the category "ethnic stereotype" as an element of the cognitive process is emphasized in most studies on interpersonal and intergroup relations in different ethnic groups, processes of intercultural interaction [1, p. 567]. To simplify communication with the complex surrounding world, a person creates a form of the image of the world (a simplified image of the world) determined by culture. A stereotype is a stable cognitive image formed by the culture of the people; it is ahead of the human mind, completely falls into the forms of the created image of the world, acts as a social image of people of a certain ethnic group. We choose what our culture has already determined for us, and we tend to perceive what we have chosen in the form of a stereotype created for us by our culture. This process is a type of peculiar closure that imposes a certain content on the cognitive process even before the incoming information reaches the human mind. Ethnic stereotype 
has two sides - cognitive (content) and affective (prejudice). The setting gives the cognitive side of the stereotype the content, focus and determines its intensity. First, an installation is formed in a person, and then the installation is filled with the content corresponding to this installation. That is, an ethnostereotype can take shape both at the level of the ordinary and at the level of theoretical consciousness. Based on the functioning of the ethnic stereotype, it is possible to predict behavior and, based on the forecast, establish a psychological and at the same time, communicative distance that regulates the process of intercultural communication, where one compares one's own with another.

The strength of the ethnic stereotype is enormous, members of the ethnos perceive it as the only worthy, and all others as savagery. L.N. Gumilev believed that the process of the active adaptation of human groups in the ethnic and natural environment forces people to develop complexes of adaptive skills i.e. a unique ethnic stereotype of behavior, which is a "regulatory tool of ethnic self-consciousness" [5, p. 189], a cognitive tool to maintain optimal permeability of ethnic boundaries, performing cognitive, communicative and defense functions. Each ethnic group has not only its own internal structure, but also its own unique stereotype of behavior, which makes it possible to exist in the most rational way for the existing geographical and climatic conditions and is transmitted from generation to generation in the process of socialization. The structure of the ethnic stereotype of behavior is a strictly defined norm of relations: between the collective and the individual; individuals among themselves; intraethnic groups among themselves; between an ethnic group and intraethnic groups. Ethnic stereotype is as dynamic as the ethnos itself. Sometimes the structure and stereotype of ethnos behavior change from generation to generation. This indicates that the ethnos is developing, and ethnogenesis is not fading [5, p. 92].

In similar conditions, representatives of different ethnic groups manifest themselves differently, which is explained by the presence of each ethnic group of the so-called national character, corresponding to relatively well-preserved personality traits and personality models (personality types), which are modal for adult members of this society and reflect psychological peculiarities of representatives of one or another ethnic group. None of the factors can give a satisfactory explanation of national features while ignoring the educational system that has been developing for centuries under the influence of the conditions of the material life of society. Lifestyle, practical activities affect the formation of national character, acting as factors of education. You can find out the national character by studying the national educational system [3, p. 28-34].

M. Mead considered aspects of research of a national character: a comparative description of certain cultural configurations (a comparison of the ratio of various social institutions) characteristic of a particular culture; the study of models of interpersonal relations inherent in one or another culture. Here national character is considered as a system of attitudes, values and beliefs adopted in this society.

The concept of tradition is important, encompassing all methods of fixing, assimilating, transmitting and reproducing ethnic culture, the focus of cultural paradigms that are based on cultural values that provide "...the upbringing of a positive attitude to cultural differences" [4, p. 7-10]. A. Royce called tradition a historical style. The concept of tradition, as well as the term culture, has many meanings, sometimes mutually exclusive.

Until the 60's of the 20th century, tradition was understood as an invariable, inflexible legacy of the past i.e. a rudiment that was supposed to disappear as the previous stage of social development, incapable of resisting modernity. Traditional societies were understood as pre-capitalist social structures. The basis of a simplified understanding of tradition was the wide spread of evolutionist views on the progressive-stage development of society at the beginning of the 20th century. 
In the first half of the 60's of the 20th century, it became obvious that modernity cannot be unambiguously opposed to tradition, since the traits that were considered characteristic only of the present turned out to be inherent in traditional societies. A view arises of tradition as a category, designed to cover all methods of fixing, transmitting and reproducing culture, including forming a religious consciousness, "emphasizing the influence on the philosopher of theological ideas ..." [8, p. 29-31], noting "the influence of Orthodoxy on the formation and design of Russian culture" [11, p. 39-44]. The concept of tradition is separated from the concepts of custom and rite as a more general, selective. The idea began to be expressed that tradition and innovation, tradition and modernity are interconnected and interdependent.

L. Rudolph and S. Rudolph showed that traditional institutions that were previously considered to be highly stable and unchanged and therefore unconditionally opposed the forces of modernity and economic development, not only coexist side by side with modern institutions, but also adapt to their requirements, mutating and acting as conductors of modernity in the context of this traditional social organization. According to F. Riggs, a traditional society is evolving into a socio-political system of a new type, and such a new system, often still characterized as traditional or transitional, develops its own systemic characteristics, forming an original mechanism of self-reproduction and maintaining stability. By tradition, we understand the totality of those objects and ideas whose origins are rooted in the past, but which can be found in the present, that is, all that has not been destroyed. In this case, tradition is tantamount to a heritage i.e. to what is really preserved from the past. Any tradition, regardless of content, can restrain creativity or innovation by offering readymade recipes for solving modern problems.

According to S. Eisenstadt, tradition is an integral element of any social culture as any social organization as a whole (whether it is the so-called traditional or modern society), and each of its elements separately (traditions, for example, retain their significance even in such most rationalized and dynamic areas of human activity as science and technology). Two functions of culture: maintaining order and changing order, represent two sides of the same coin. Traditional society is constantly changing. He considers tradition as something that is in the process of constant change, and these changes can be both small and global, associated with the transformation of the whole society. In tradition, there are creative and conservative components in the dual unity. The nature of changes in traditional society is set from within.

D.I. Vodzinsky believes that traditions are established, inherited from previous generations and supported by the power of public opinion forms of behavior of people and their relationships or principles by which universal human culture develops. According to S. A. Arutyunov, tradition is a group experience expressed in socially organized stereotypes, which is accumulated and reproduced in various human groups through a spatiotemporal transmission. In tradition, there are creative and conservative components. Any tradition was once an innovation, any innovation has a chance to become a tradition, and the adaptive lability of tradition lies precisely in the ability to assimilate innovations. K.D. Radina believes that traditions are firmly established, periodically repeated, elements of organization of the collective's activity that differ in a certain order of construction, a source of value orientations that deepen and differentiate the individual's experiences. Preservation and development of traditions in the structure of national culture is a guarantee from stagnation in its development.

According to the concept of the central zone of culture, following tradition is essentially the realization of various variations of the central cultural theme of the ethnic group perceived from previous generations. Tradition is not something self-reproducing and selfdeveloping. Only a living, cognizing, desiring human being can perceive it and modify it. 
The tradition develops because the one who is its carrier, strives to create something better, more suitable. During the modification of the cultural tradition in the ethnos, specific processes of enrichment of the ethnoculture take place.

At present, the thesis about the variability and flexibility of the cultural tradition is accepted, it is perceived as something movable and varied. The tradition develops because the one who is its carrier, seeks to create something better, more suitable. In tradition, there are creative and conservative components in the dual unity. Tradition and innovation are interconnected and interdependent. Each tradition was once an innovation, any innovation has a chance to become a tradition, and it is precisely in the ability to assimilate innovations that the vitality, adaptive lability of tradition lies.

The system of traditions of any nation is the result of its educational efforts for many centuries. Through this system, people reproduce themselves, their spiritual culture, their national character and the psychology of successive generations. Tradition is the most important means of transmitting and mastering ethnocultural experience. This gives grounds to consider ethnoculture as knowledge of the features of the form of existence, development, continuity of the transmission of the historical content of the spiritual activity of a given community, some specific aspects of the very content of the concept of ethnoculture, national specificity accumulated over the centuries regarding the separate existence of peoples, the qualitative certainty of their spiritual life, fixed, expressed in peculiar traditions, values and cultural institutions.

Despite any innovations and creativity of culture, an ethnos needs to maintain a connection between generations in order to reproduce itself and self-regulate. Experience shows that every nation is trying not only to preserve the ethnocultural traditions that have developed historically, but also seeks to transfer them into the future so as not to lose their ethnic identity. Traditions act as mechanisms for transferring the experience of the older generation. This is the essence of succession. Due to it, the transmission and development of the basic values, traditions, ideas, forms and means of ethnocultural development are ensured, which are passed down from generation to generation, developing, enriching and mutating. Traditions, customs, ceremonies act as a means of communication between the individual and society. They have an impact on thinking, morality and increase their responsibility to society.

G.N. Volkov distinguishes several types of succession. Physical succession is ensured by nature: heredity, genotype, the relationship with the ancestors is recognized, the biography of the genus as a kind of history, connected with a common origin, spiritually nourishes the continuity of generations, the instinct of preservation, continuation of the genus. Spiritual succession is ensured by upbringing, the desire for spiritual self-preservation in the descendants and in the continuation of oneself in the students, their own children. Continuity in the field of labor interests and art (traditional crafts transmitted from generation to generation). The continuity of the community plan is in the moral sphere, in the conscious desire of parents to make children live better, to become better, in blessing the newlyweds, in wedding rituals, well-being of the newborn, and the spelling of the name. Material and economic succession is carried out by inheritance. Thanks to historical continuity, the continuity of the basic ideas, forms and means of ethnocultural development is ensured. They are transmitted from generation to generation, developing, enriching and mutating. Historical continuity as the highest value "... is based on a real presence ... in the human mind" [13, p. 31-34]. All the best that is in culture is inherited from their ancestors. The idea of historical permanence is one of the most creative ideas. Particular importance is given to the education of historical memory [15, p. 41-47]. Without historical memory, there are no traditions, without traditions, there is no culture, without culture, there is no 
upbringing, without upbringing, there is no spirituality, without spirituality, there is no person, without person, there is no people.

Syncretism is manifested in the fact that all types of succession appear in continuous unity with all social institutions, the social life of the people, with their cult rites, beliefs, traditions, customs, types of economic activities, and norms of social behavior.

The transfer of culture from generation to generation includes the development of the experience accumulated by humankind, but does not coincide with the utilitarian mastery of the results of previous activities. Cultural continuity is not carried out automatically; it is necessary to organize a system of upbringing and education based on the scientific study of the forms, methods, directions and mechanisms of personality development [9, p. 1518].

Traditions and continuity ensure the stability of culture, contribute to the "dialogue of cultures in the context of the development of modern civilization" [12, p. 145-160]. It is important to take care of traditions, preserving ethnic characteristics as the organic part of culture, which does not mean the rigidity of the culture itself, but about the enduring moral value of national experience. To ensure the succession and stability of the forms of existence of ethnic communities, the effective functioning of the channels of the social inheritance program is required. They provide the continuity of the existence of an ethnic group.

L. N. Gumilyov's tradition of culture is the sum of knowledge and ideas transmitted over time from an ethnos to an ethnos [5, p. 498]. Borrowing of foreign and international elements of material and spiritual culture, significant changes in the social structure of ethnic groups, changes in the demographic structure are taking place.

Cultural tradition is a very flexible and agile thing. Nevertheless, it sets a certain logic of borrowing. Borrowing the elements of one culture from another cannot occur as a mechanical process and is not an automatic consequence of cultural contacts. When this happens, the borrowed element of culture is rethought and takes on a different meaning in another culture. Every nation or its individual representatives, mechanically borrowing other spiritual values, types of thinking, lose their ability to create, create within the framework of their native and other cultures.

\section{Лumepamypa}

1. Авдеев Е.А., Бакланов И.С., Бакланова О.А. Социокультурная динамика современности: трансорормация коммуникационного пространства культуры. Современные проблемы науки и образования. 2014. № 4. С. 567.

2. Бакланова О.А., Бакланов И.С. Контуры типологического исследования социальности современного общества. Известия Саратовского университета. Новая серия. Серия: Философия. Психология. Педагогика. 2014. Т. 14. № 2-1. С. 5-10.

3. Говердовская E.B. Социокультурные и этнологические особенности региона основа модернизации высшего образования на Северном Кавказе. Ученые записки университета им. П.Ф. Лесгафта. 2007. № 7. С. 28-34.

4. Говердовская Е.В. Особенности проектирования образовательного пространства высшей школы в поликультурном регионе. Экономические и гуманитарные исследования регионов. 2014. №4. С. 7-10.

5. Гумилев Л.Н. Этногенез и биосфера Земли. Л.Н. Гумилев. М.: Рольф, 2001. 560 c.

6. Ерохин А.М. Социально-фрилософские аспекты развития культурной сферы общества. Экономические и гуманитарные исследования регионов. 2016. № 1. С. 74-78. 
7. Ерохин А. М. Научно-информационный аспект исследования социокультурного развития общества в области культуры и искусства. Экономические и гуманитарные исследования регионов. 2015. № 2. С. 123-128.

8. Камалова О.Н. «Созерцание» в философско-культурологических построениях И. Ильина. Гуманитарные и социально-экономические науки. 2012. № 6. С. 2931.

9. Лобейко Ю.А. Социально-педагогический аспект активности личности в системе общественного развития. Экономические и гуманитарные исследования регионов. 2015. № 1. С. 15-18.

10.Лобейко Ю.А. Социальная активность личности в обществе: социальнопедагогические аспекты формирования. European Social Science Journal. 2014. №7-2 (46). С. 282-284.

11. Матяш Т.П., Несмеянов Е.Е. Православный тип культуры: идея и реальность. Гуманитарные и социально-экономические науки. 2015. № 3 (82). С. 39-44.

12. Несмеянов E. E. «Цивилизация молодых»: идея и реальность. Гуманитарные и социальные науки. 2013. № 6. С. 145-160.

13. Шеярф Г. А., Камалова О. Н. Некоторые аспекты проблемы гносеологического статуса религии в русской религиозной философии: С.Н. Булгаков, П.А. Флоренский, С.Л. Франк. Гуманитарные и социально-экономические науки. 2013. №4 (71). C. 31-34.

14. Berkovskiy V., Tronina $L$. Social and historical aspect of interaction of ethnic culture and personality in the context of public development. Научный альманах стран Причерноморья. 2019. № 1 (17). С. 3-9.

15. Kuleshin M., Leonova N., Nemashkalov P. Historical consciousness as a part of national consciousness: to the problem statement of the research. Научный альманах стран Причерноморья. 2019. № 1 (17). С. 41-47.

\section{References}

1. Avdeyev Ye.A., Baklanov I.S., Baklanova O.A. Sotsiokulturnaya dinamika sovremennosti: transformatsiya kommunikatsionnogo prostranstva kultury. Sovremennyye problemy nauki i obrazovaniya. [Sociocultural dynamics of the present: transformation of the communication space of culture. Modern problems of science and education]. 2014. No. 4. 567 p. (in Russian).

2. Baklanova O. A., Baklanov I.S. Kontury tipologicheskogo issledovaniya sotsial'nosti sovremennogo obshchestva. Izvestiya Saratovskogo universiteta. Novaya seriya. Seriya: Filosofiya. Psikhologiya. Pedagogika. [Outlines of a typological study of the sociality of modern society]. 2014. V. 14. No. 2-1. pp. 5-10 (in Russian).

3. Goverdovskaya Ye.V. Sotsiokul'turnyye i etnologicheskiye osobennosti regiona - osnova modernizatsii vysshego obrazovaniya na Severnom Kavkaze. Uchenyye zapiski universiteta im. P.F. Lesgafta. [Socio-cultural and ethnological features of the region are the basis for the modernization of higher education in the North Caucasus. Scientific notes of the University. P.F. Lesgaft]. 2007. No. 7. pp. 28-34 (in Russian).

4. Goverdovskaya Ye.V. Osobennosti proyektirovaniya obrazovatel'nogo prostranstva vysshey shkoly v polikul'turnom regione. Ekonomicheskiye i gumanitarnyye issledovaniya regionov. [Features of designing the educational space of a higher school in a multicultural region. Economic and Humanitarian Studies of the Regions]. 2014. No. 4. pp. 7-10 (in Russian).

5. Gumilev L.N. Etnogenez i biosfera Zemli. L.N. Gumilev. [Ethnogenesis and the Biosphere of the Earth]. Moscow: Rol'f, 2001. 560 p. (in Russian). 
6. Kamalova O. N. «Sozertsaniye» v filosofsko-kul'turologicheskikh postroyeniyakh I. Il'ina. Gumanitarnyye i sotsial'no-ekonomicheskiye nauki. ["Contemplation" in the philosophical and cultural studies of I. Ilin. Humanitarian and socio-economic sciences]. 2012. No. 6. pp. 29-31 (in Russian).

7. Lobeyko Yu.A. Sotsial'no-pedagogicheskiy aspekt aktivnosti lichnosti v sisteme obshchestvennogo razvitiya. Ekonomicheskiye i gumanitarnyye issledovaniya regionov. [Socio-pedagogical aspect of personality activity in the system of social development. Economic and Humanitarian Studies of the Regions]. 2015. No. 1. pp. 15-18 (in Russian).

8. Lobeyko Y.A. Sotsial'naya aktivnost' lichnosti v obshchestve: sotsial'nopedagogicheskiye aspekty formirovaniya. European Social Science Journal. [Social activity of the individual in society: social and pedagogical aspects of the formation. European Social Science Journal]. 2014. No. 7-2(46). pp. 282-284.

9. Matyash T.P., Nesmeyanov Ye.Ye. Pravoslavnyy tip kul'tury: ideya i real'nost'. Gumanitarnyye i sotsial'no-ekonomicheskiye nauki. [Orthodox type of culture: the idea and reality. Humanitarian and socio-economic sciences]. 2015. No. 3 (82). pp. 39-44 (in Russian).

10. Nesmeyanov Ye.Ye. «Tsivilizatsiya molodykh»: ideya i real'nost'. Gumanitarnyye i sotsial'nyye nauki. ["Civilization of the young": the idea and reality. Humanities and social sciences]. 2013. No. 6. pp. 145-160 (in Russian).

11. Sheff G. A., Kamalova O. N. Nekotoryye aspekty problemy gnoseologicheskogo statusa religii v russkoy religioznoy filosofii: S.N. Bulgakov, P.A. Florenskiy, S.L. Frank. Gumanitarnyye i sotsial'no-ekonomicheskiye nauki. [Some aspects of the problem of the epistemological status of religion in Russian religious philosophy: S.N. Bulgakov, P.A. Florensky, S.L. Franc. Humanitarian and socio-economic sciences]. 2013. No. 4 (71). pp. 31-34 (in Russian).

12. Yerokhin A.M. Sotsialno-filosofskiye aspekty razvitiya kulturnoy sfery obshchestva. Ekonomicheskiye i gumanitarnyye issledovaniya regionov. [Socio-philosophical aspects of the development of the cultural sphere of society. Economic and humanitarian studies of the regions]. 2016. No. 1. pp. 74-78 (in Russian).

13. Yerokhin A.M. Nauchno-informatsionnyy aspekt issledovaniya sotsiokul'turnogo razvitiya obshchestva $v$ oblasti kul'tury i iskusstva. Ekonomicheskiye i gumanitarnyye issledovaniya regionov. [Scientific and informational aspect of the study of sociocultural development of society in the field of culture and art. Economic and Humanitarian Studies of the Regions]. 2015. No. 2. pp. 123-128 (in Russian).

14. Berkovskiy V., Tronina L. Social and historical aspect of interaction of ethnic culture and personality in the context of public development. Science Almanac of Black Sea Region Countries. 2019. №1 (17). pp. 3-9.

15. Kuleshin M., Leonova N., Nemashkalov P. Historical consciousness as a part of national consciousness: to the problem statement of the research. Science Almanac of Black Sea Region Countries. 2019. №1 (17). pp. 41-47. 